\title{
Experimental Testing and Validation of the Mathematical Model for a Self-Humidifying PEM Fuel Cell
}

\author{
Ibrahim M. Saleh ${ }^{*}$, Rashid Ali², Hongwei Zhang1 \\ ${ }^{1}$ Materials and Engineering Research Institute, Sheffield Hallam University, Sheffield, UK \\ ${ }^{2}$ Faculty of Engineering, Environment and Computing, Coventry University, Coventry, UK \\ Email: ^ibrahim.saleh@student.shu.ac.uk,Ac4329@coventry.ac.uk,h.zhang@shu.ac.uk
}

How to cite this paper: Saleh, I.M. Ali, R. and Zhang, H.W. (2018) Experimental Testing and Validation of the Mathematical Model for a Self-Humidifying PEM Fuel Cell. Journal of Materials Science and Chemical Engineering, 6, 202-218. https://doi.org/10.4236/msce.2018.64019

Received: April 10, 2018

Accepted: April 27, 2018

Published: April 30, 2018

Copyright $\odot 2018$ by authors and Scientific Research Publishing Inc. This work is licensed under the Creative Commons Attribution International License (CC BY 4.0).

http://creativecommons.org/licenses/by/4.0/

\begin{abstract}
This paper presents an experimental testing and validation results for a zero-dimensional self-humidifying PEM (Proton Exchange Membrane) fuel cell stack. The model incorporates major electric and thermodynamic variables and parameters involved in the operation of the PEM fuel cell under different operational conditions. The mathematical equations are modelled by using Matlab-Simulink tools in order to simulate the operation of the developed model with a commercially available $1 \mathrm{~kW}$ Horizon (H-1000) PEM fuel cell stack, which is used for the purposes of model validation and tuning of the developed model. The model is mathematically modelled and presented in the recent published work of authors. The observations from model simulations provide sufficient evidence and support to the results and observations obtained from testing $1 \mathrm{~kW}$ Horizon (H-1000) PEM fuel cell stack used in this research. The developed model can be used as a generic model and simulation platform for a self-humidifying PEM fuel cell with an output power varying from $50 \mathrm{~W}$ to $1 \mathrm{~kW}$, with extrapolation to higher powers is also possible.
\end{abstract}

\section{Keywords}

PEM Fuel Cell, Self-Humidifying, Modelling, Simulation

\section{Introduction}

A fuel cell is a device which directly converts the energy in the reactants into electricity. The efficiency of energy conversion-production for the fuel cell is comparatively higher than internal combustion engines because there is no intermediate thermal conversion process similar to the internal combustion en- 
gines or gas turbines [1]. The increasing demand on the electrical energy has resulted in an increase in the production which in turn has increased harmful emissions, which is the core of the growing concern of the global warming [2]. The pollutants such as carbon dioxide, nitrous oxides, and sulphur dioxide which are produced from combusting hydrocarbon fuels are eliminated in the case of the fuel cells. Also the absence of intermediate mechanical conversion process makes a fuel cell a quiet device [3].

PEM fuel cells have several features comparing to other types of fuel cells, such as: low corrosion, low weight and compact size, which make them suitable for mobile and stationary applications. The operational temperatures of the PEM fuel cell range between $30^{\circ} \mathrm{C}-100^{\circ} \mathrm{C}$, with a dynamical response faster than solid oxide fuel cell which operates at temperatures over $700^{\circ} \mathrm{C}$ [4] [5] [6].

A one dimensional isothermal steady-state model for a PEM fuel cell with Nafion 117 membrane has been developed [7] to determine the impact of water transport mechanisms on the performance of the fuel cell. [8] Investigated the conductivity of Nafion117 membrane as a function of drawn current densities. While, [1] adopted the model developed by [9] in order to consider the impact of heat transfer between the fuel cell body, gas channels, and cooling water.

A non-linear dynamic model of the PEM fuel cells using electrochemical-thermodynamic and zero-dimensional fluid mechanics principles has been developed [10]. While, [11] developed a non-isothermal one dimensional model of a PEM fuel cell is in order to investigate and examine the impact of the design and operating conditions on the performance of the PEM fuel cell.

A simple dynamic electrical model of a PEM fuel cell has been developed by [12] via extending the static current-voltage behavior of the model to implicit the impact of the temperature on the performance of the fuel cell. [13] Developed a dynamic model of $1.2 \mathrm{~kW}$ PEM fuel cells that is used for optimal operational strategies development and to control design of the fuel cell based power systems.

A new dynamic model of 20 cells stack has been proposed [14] to investigate starting up and transient behavior of the model under different conditions of load current, temperature, and coolant flow rate. The impact of temperature and the two phases of water (gas and liquid) in the gas diffusion layer need to be taken into consideration. While, [15] a lumped model of the PEM fuel cells is developed to determine the impact of various operating and design parameters such as: input temperature, pressure, stoichiometric ratio, thickness of membrane and gas diffusion layer on the performance of the fuel cell.

A three-dimensional multi-phase fuel cell model has been developed [16] to predict the impact of operating parameters such as operating pressure and temperature of the fuel cell, relative humidity of reactant gases, and air stoichiometric ratio on the performance of the PEM fuel cells operates under steady-state conditions. While, [17] a mathematical model of a $750 \mathrm{~W}$ PEM fuel cell is developed to predict the behavior of the fuel cells under steady and transient states.

Although many of the fuel cell models are available in literatures, but most of 
these models estimate the output voltage of the fuel cell for a particular set of operating conditions and some often for a limited dynamic variations. The proposed model in this paper presents a simplified zero-dimensional mathematical model for a self-humidifying $1 \mathrm{~kW}$ PEM fuel cell developed by modelling the major electric and thermodynamic variables and parameters involved in the operation of a PEM fuel cell.

\section{Modelling of the PEM Fuel Cell}

A simplified mathematical model of the self-humidifying PEM fuel cell is developed by modelling the major electric and thermodynamic variables and parameters, as it was mathematically modelled and presented in the recent published work of the authors in [18]. Consideration is given to the changes in the environmental conditions, changes in the dynamical properties of the fluids in the supply-return manifolds and inside the anodes and cathodes of the fuel cell stack, properties such as pressure, temperature, and flow rates. Hence, the proposed model can determine the impact of: load current, changes in the pressure and temperature of the surroundings, stack operating temperature, water vapour across the membrane, relative humidity in the cathodes and anodes and the water content in the electrolyte membrane, thickness of the membrane and the size of membrane active area, and the volume of the cathode and anode up on the performance and output power of the fuel cell stack, the usage of pure oxygen or fresh air is considered as well. Thus, this model can be used by the interested researchers as a generic model and simulation platform of a self-humidifying PEM fuel cell with an output power varying from $50 \mathrm{~W}$ to $1 \mathrm{~kW}$. Moreover, extrapolation to higher powers is also possible.

Matlab-Simulink tools is used in order to simulate the operation of the developed model with a commercially available $1 \mathrm{~kW}$ Horizon (H-1000) PEM fuel cell stack which is used as an experimental device in running the test physically in order to validate and tune the developed model. The electric and thermodynamic governing equations of the developed model were mathematically modelled and used to determine the output voltage of the PEM fuel cell stack as a function to the changes of: fuel cell temperature, water content in the membrane, dimensions and volumes of the fuel cell and membrane, drawn current from the cell, and pressure and the flow rates of the hydrogen and oxygen inside the fuel cell, as presented in the previously published work of the authors in [18].

The output voltage of the PEM fuel cell $V_{f c}$ is subject to various losses, and could be expressed by the following equations.

$$
\begin{gathered}
V_{f c}=n *\left(E_{o c}+V_{a c t}+V_{o h m}+V_{c o n}\right) \\
E_{o c}=1.228-\left(0.85 * 10^{-3} *(T-298.15)\right)+\left(4.3086 * 10^{-5} * T \cdot \operatorname{Ln}\left(P_{\mathrm{H}_{2}} \cdot\left(P_{\mathrm{O} 2}\right)^{1 / 2}\right)\right) \\
V_{a c t}=\zeta_{1}+\zeta_{2} \cdot T+\zeta_{3} \cdot T \cdot \operatorname{Ln}\left(\frac{P_{\mathrm{O} 2}}{5.08 * 10^{6} * \exp (-498 / T)}\right)+\zeta_{4} \cdot T \cdot \operatorname{Ln}(I)
\end{gathered}
$$




$$
\begin{gathered}
V_{\text {ohm }}=-I \cdot \frac{l}{A_{f c}} \cdot\left(\frac{181.6\left[1+0.03\left(\frac{I}{A_{f c}}\right)+0.062\left(\frac{T}{303}\right)^{2} \cdot\left(\frac{I}{A_{f c}}\right)^{2.5}\right]}{\left[\lambda-0.634-3\left(\frac{I}{A_{f c}}\right)\right] \cdot \exp \left[4.18\left(\frac{T-303}{T}\right)\right]}\right) \\
V_{\text {con }}=\frac{3 R T}{4 F} \operatorname{Ln}\left(1-\frac{i}{i_{m}}\right)-1.5607 \frac{R T}{4 F}
\end{gathered}
$$

where, $E_{o c}$ represents open circuit voltage of the PEM fuel cell as it has been derived previously for a liquid state of water produced by the fuel cell and given by [19]. $V_{\text {act }} V_{\text {ohm }}$, and $V_{c o n}$, represent the activation overvoltage, ohmic overvoltage, and concentration overvoltage of the PEM fuel cell, respectively. $n$ is the number of cells connected in series in the stack. $T$ is stack temperature in Kelvin which is nearly equal to cell temperature. $I$ is the drawn current in Ampere, and $\zeta_{n}$ represents the empirical parametric coefficient based on the experimental data, which may vary from one stack to another or cell to another depends on the geometrical design and the materials used in the construction of the PEM fuel cell. $A_{f c}$ is the membrane active area $\left(\mathrm{cm}^{2}\right)$, and $I$ is the thickness of membrane $(\mathrm{cm}) . R$ is the universal gas constant, and $F$ is Faraday's constant.

The mass flow rate of air flows between the exit of supply manifold $W_{\text {sm,outca }}$ and the cathode is determined as given in the equation below [18],

$$
W_{\text {sm,out }, \text { ca }}=K_{\text {sm,out }, c a} \cdot\left(P_{\text {sm,out }, c a}-P_{c a, i n}\right)
$$

where, $P_{c a, i n}$ is the pressure of air enter the cathode, and $W_{\text {sm,out }, c a}$ is assumed to be equal to $W_{s m, i n, c a}$ under condition of steady flow. $k_{s m, o u t, c a}$ is the nozzle constant of supply manifold outlet $(\mathrm{kg} / \mathrm{s} \cdot \mathrm{kPa})$ which represents the ratio of mass flow rate of air to the pressure. While, the pressure of air enter and exit the cathode can be determined as given in equation below [18],

$$
P_{c a, o u t}=P_{c a, i n}+\frac{R \cdot T_{s t}}{V_{c a}}\left(\frac{m_{w, g e n}-m_{w, m b r}}{M_{w}}-\frac{m_{O 2, r c t}}{M_{O 2}}\right)
$$

where, $m_{w, g e n}, m_{w, m b r}$ and $m_{O 2, r c t}$ represent mass $(\mathrm{kg})$ of produced water as a result of electrochemical reaction, the mass of water vapour across the electrolyte membrane, and the mass of reacted oxygen in the cathode, respectively, $V_{c a}$ is the volume of cathode $\left(\mathrm{m}^{3}\right)$, and $T_{s t}$ is the stack temperature. $M_{w}$ and $M_{O 2}$ represents the molar mass of water and oxygen $(\mathrm{kg} / \mathrm{mol})$, respectively. The mass flow rate of hydrogen at the exit of the supply manifold of anode $W_{s m, o u t, a n}$ is determined by the equation below [18],

$$
W_{\text {sm,out }, a n}=K_{\text {sm,out }, a n} \cdot\left(P_{\text {sm,out }, a n}-P_{a n, i n}\right)
$$

where, $P_{a n, i n}$ is the pressure of hydrogen enter the anode, and $W_{\text {sm,out,an }}$ is assumed to be equal to $W_{s m, i n, a n}$ under condition of steady flow. $k_{s m, o u t, a n}$ represents the nozzle constant of supply manifold outlet of anode $(\mathrm{kg} / \mathrm{s} \cdot \mathrm{kPa})$, which represents the ratio of mass flow rate of hydrogen to the pressure. While, the pressure of 
hydrogen enter and exit the anode can be determined as given in equation below [18].

$$
P_{a n, o u t}=P_{a n, i n}-\frac{R \cdot T_{s t}}{V_{a n} \cdot M_{H 2}} \cdot m_{H 2, r c t}
$$

where, $V_{a n}$ is the volume of anode $\left(\mathrm{m}^{3}\right), m_{H 2, r c t}$ represents mass of the reacted hydrogen $(\mathrm{kg})$, and $M_{H 2}$ is the molar mass of pure hydrogen $(\mathrm{kg} / \mathrm{mol})$, and $W_{H,, r c t}$ is the mass flow rate of the reacted hydrogen as a result of electrochemical reaction.

In this research, Horizon (H-1000) fuel cell stack system is adopted as an experimental prototype, which is designed by the manufacturer to be self-humidified fuel cell stack [20]. Figure 1 shows the mechanical components and flow variables associated with the Horizon (H-1000) fuel cells stack system. It has been assumed that all the gases inside the stack of the fuel cells will behave as an ideal gas; also the properties of gases leaving the specific volume are the same as those inside that volume. The dimensions of the Horizon (H-1000) fuel cell stack are relatively small, hence the distances between the supply-return manifolds and anodes-cathodes of the fuel cell are small, therefore it is assumed the impact of heat radiation or conduction between anodes-cathodes and supply-return manifolds are very small and can be ignored. Hence, the temperature of gases in the anodes-cathodes and also along the supply-return manifolds will be uniform and equal to the stack temperature. Moreover, because of the small size of the stack, it is assumed that the flow of gases within any cross sections in the stack has approximately zero flow fractions. Also, it has been assumed that the average stack temperature and relative humidity inside the cathode and anode are well regulated and maintained for all the stages of modelling, analysis, and control design [18].

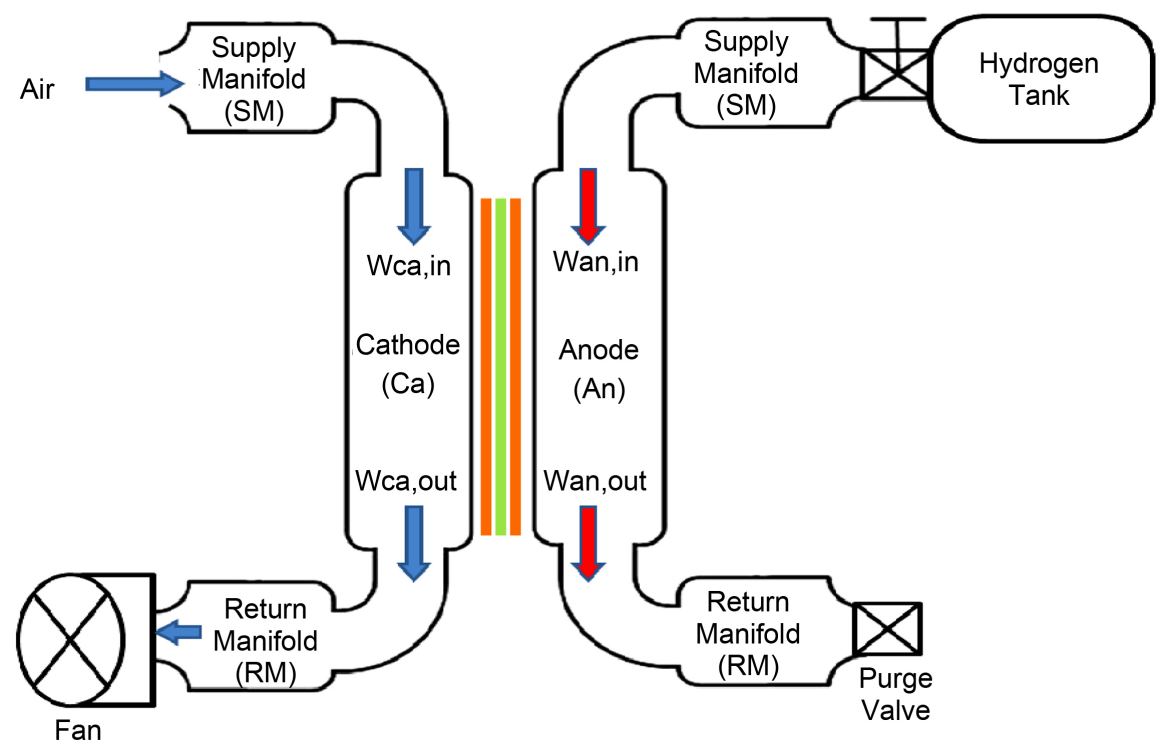

Figure 1. Mechanical components and flow variables associated with the Horizon (H-1000) fuel cells stack system at sea level operation. 


\section{Validation of the Developed Model of a PEM Fuel Cell}

Horizon (H-1000) $1 \mathrm{~kW}$ PEM fuel cell stack is used as an experimental device in running the test physically in order to validate and tune the developed mathematical model of PEM fuel cell. The developed model is simulated under operating conditions of room temperature, stack temperature, and drawn current similar to the real operating condition of the tested Horizon stack in the laboratory.

Different values of tuning are adopted for the developed model, in order to find the best tuning value, which enables the developed model to perform and produce a steady state output voltages and currents close to the output voltages and currents of the tested stack. Moreover, in order to get the most accurate real data outputs, the test of the PEM fuel cell stack is repeated several times on different occasions, in order to achieve a minimum deviation between the output voltages of the tested stack and output voltages of the developed model, also a closeness in the behaviour and steady state performance between the tested stack and the developed model.

Horizon fuel cell stack (H-1000) is designed to have four fans installed at the exit outlet of the return manifolds of cathodes. Hence, fans are configured as a ducted inlet-free outlet, working as suction devices at the outlet of the return manifolds of cathodes. The rotational speed of the four axial fans and the frequency of purging for the outlet hydrogen valve every 10 seconds are controlled by an inbuilt stack's controller, in order to maintain enough operational pressure at the cathode and anode, and also to provide a sufficient flow of air and hydrogen leading to maintaining a certain level of stack temperature and retaining the continuity of the electrochemical reaction. The controller provides a protection shutdown for the stack at $30 \mathrm{~A}$ over current and $36 \mathrm{~V}$ low voltage operation [20].

An AttoPilot $50 \mathrm{~V} / 90 \mathrm{~A}, \mathrm{DC}$ voltage-current senor with 2 analog outputs is used to measure the output voltages and currents from the stack via stepping down the detected voltage and current at a ratio of $(63.69 \mathrm{mV} / 1 \mathrm{~V})$, and $(36.6$ $\mathrm{mV} / 1 \mathrm{~A}$ ). A USB interface data acquisition (NI USB-6008) with 8 analog inputs and 2 analog outputs ports is used to capture the real time currents and voltages, while LabVIEW v13.0 software is used for the purpose of data recording and analysis, with sampling frequency set on $1 \mathrm{~Hz}$. SkyRC i-Meter operates for a maximum input voltage and current of $60 \mathrm{~V}$ and $100 \mathrm{~A}$ is used to manually measure the output voltages and currents from the fuel cell stack. DC-DC Convertor (Mean Well SD-1000L-24) with an input range of $19 \mathrm{~V}$ to $72 \mathrm{~V}$ and output of $24 \mathrm{~V}$, with $40 \mathrm{~A}$ maximum current, is installed between the fuel cell stack and the BLDC motor in order to stabilise and maintain the output voltage.

A three phases, 14 poles, brushless DC Motor BLDC (KMS Quantum 4130/07) is used as an attached load to the Horizon fuel cell stack. The motor operates at supply voltage of $18.5-29.6 \mathrm{~V}$, with a maximum continuous current of $40 \mathrm{~A}$ and a maximum efficiency higher than $90 \%$, and the ratio of rotational speed (rpm) 
to the supply voltage is $360 / \mathrm{V}$. Al's Hobbies Professional analogue-digital servo tester is used to adjust the rotational speed of the BLDC motor and its propeller via generating a PWM signal to the electronic speed controller (ESC) in order to increase-decrease the current drawn from the fuel cell stack.

A pressure reduce valve (Swagelok) is used to maintain the supply pressure of hydrogen to the stack at $55 \mathrm{kPa}$. A temperature and humidity data-logger (KTH-300 Kistock), integrated with thermo-hygrometry (TH) probe sensor, is used to measure the temperature of the exit air from the stack. TH sensor is mounted at each fan outlet in an attempt to obtain an accurate estimate of temperature. The stack temperature is determined by taking the average of the sums of temperature readings for these four TH sensors. Figure 2 shows the block diagram configuration and bench layout of the Horizon (H-1000) fuel cell stack configured with measuring and controlling devices and the BLDC motor load

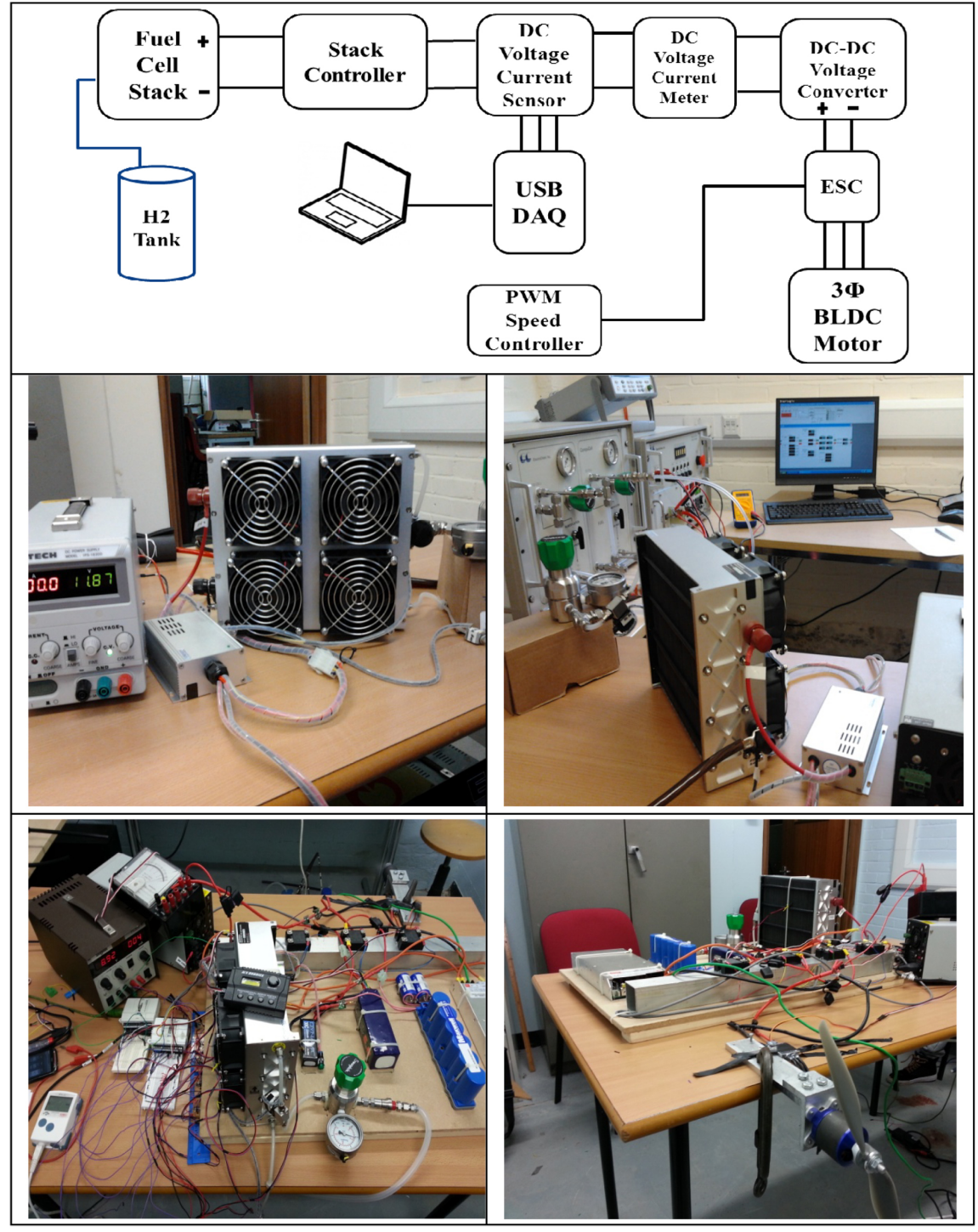

Figure 2. Bench layout of Horizon (H-1000) fuel cell stack configured with measuring and controlling devices; and BLDC motor load. 
during the testing process carried out in the laboratory. The defined values of variables and constants for the operational parameters involved in the simulation of the developed mathematical model of PEM fuel cell stack are presented in Table $\mathrm{A} 1$ in the Appendix.

\subsection{First Test}

Horizon (H-1000) PEM fuel cell stack is tested under atmospheric pressure and $23^{\circ} \mathrm{C}$ room temperature. The stack is operated for about 25 minutes under different levels of load current varied from 1 to $17 \mathrm{~A}$ in step of $1 \mathrm{~A}$, with approximate holding time of one and a half minute. One TH sensor is installed at the exit outlet of the fan in order to measure the temperature of the stack.

Different values of stack efficiency $(83 \%, 84 \%, 85 \%$, and $86 \%)$ are adopted for the developed model of PEM fuel cell stack in order to find the best tuning value between the tested stack and the developed model. It has been found that the best value of efficiency for the developed model that enables the model to perform and produce output voltages close to the stack output voltages was at $84 \%$ with $0.78 \mathrm{~V}$ average of deviation between the real test output voltages and output voltages of the developed model.

The output voltages for the tested Horizon (H-1000) fuel cell stack and the developed model are shown in Figure 3. The green line represents the output voltages as given in the data sheet of $1 \mathrm{~kW}$ Horizon (H-1000) PEM fuel cell stack, for operating condition defined at sea level and $25^{\circ} \mathrm{C}$ ambient temperature. The blue line represents output voltages of the tested stack for about 25 minutes continuous operation at $23^{\circ} \mathrm{C}$ room temperature under different levels of load current varied from 1 to $17 \mathrm{~A}$ in step of $1 \mathrm{~A}$, with approximate holding

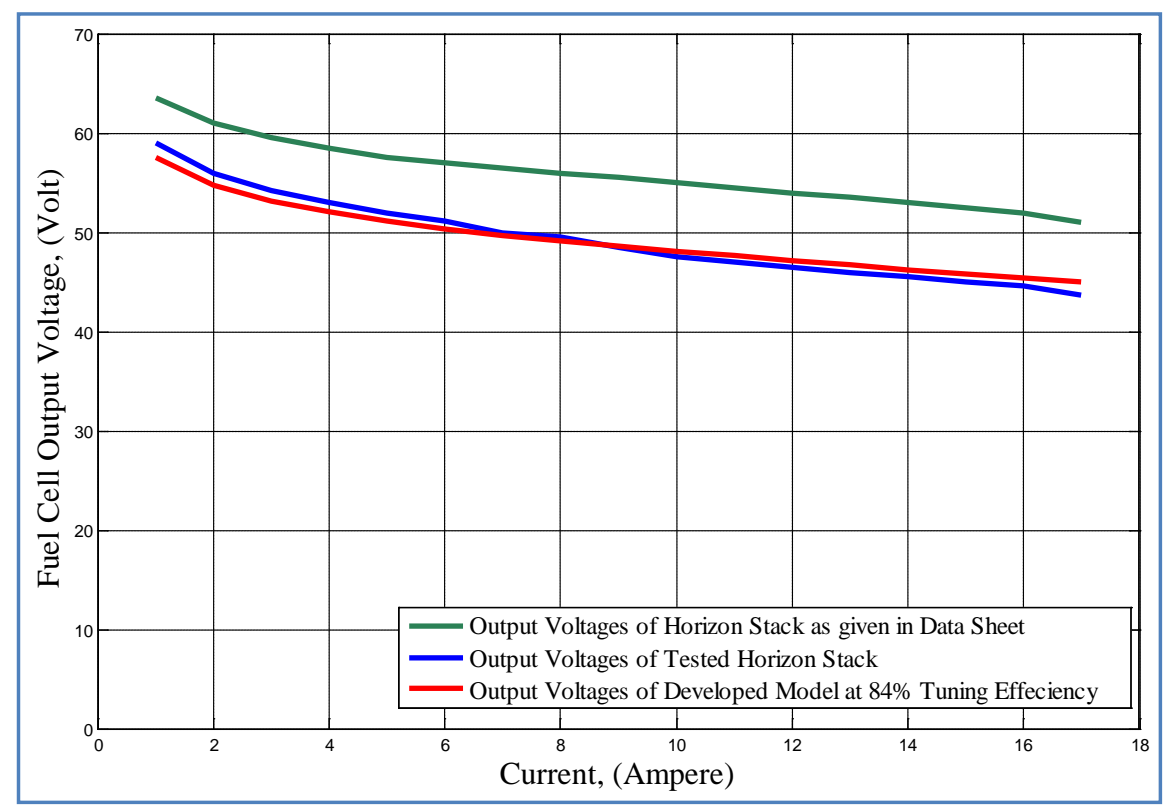

Figure 3. Output voltages for Horizon (H-1000) fuel cell stack and mathematical developed model of PEM fuel cell under various drawn load currents. 
time of one and a half minute. The red line represents output voltages of mathematical developed model based on $84 \%$ model tuning efficiency.

It is clear that the performance and output voltages of the mathematical model developed for a PEM fuel cell is fairly close to the performance and output voltages of the tested Horizon stack operated under varied levels of load current and stack temperature, which provides initial satisfaction about the validity of the developed model.

\subsection{Second Test}

Horizon (H-1000) PEM fuel cell stack is tested under atmospheric pressure and $18^{\circ} \mathrm{C}$ room temperature. The stack is operated for about 38 minutes under different levels of current load varied from 0 to $25 \mathrm{~A}$, with approximate holding time of two minutes. Four TH sensors are installed at the exit outlets of the four fans in order to have more accurate temperature measurements. The impact of drawn load current and the time of operation upon the temperature of Horizon (H-1000) fuel cell stack are measured and presented in Figures 4-6, respectively.

\subsection{Third Test}

Horizon (H-1000) PEM fuel cell stack is tested under atmospheric pressure and $20^{\circ} \mathrm{C}$ room temperature. The stack is operated for about 43 minutes under different levels of current load varied from 1 to $20 \mathrm{~A}$, with approximate holding time of three minutes. Data acquisition is set to capture and record the output voltages and currents from the stack at every 30 seconds. Four TH sensors are installed at the exit outlets of the four fans in order to have more accurate

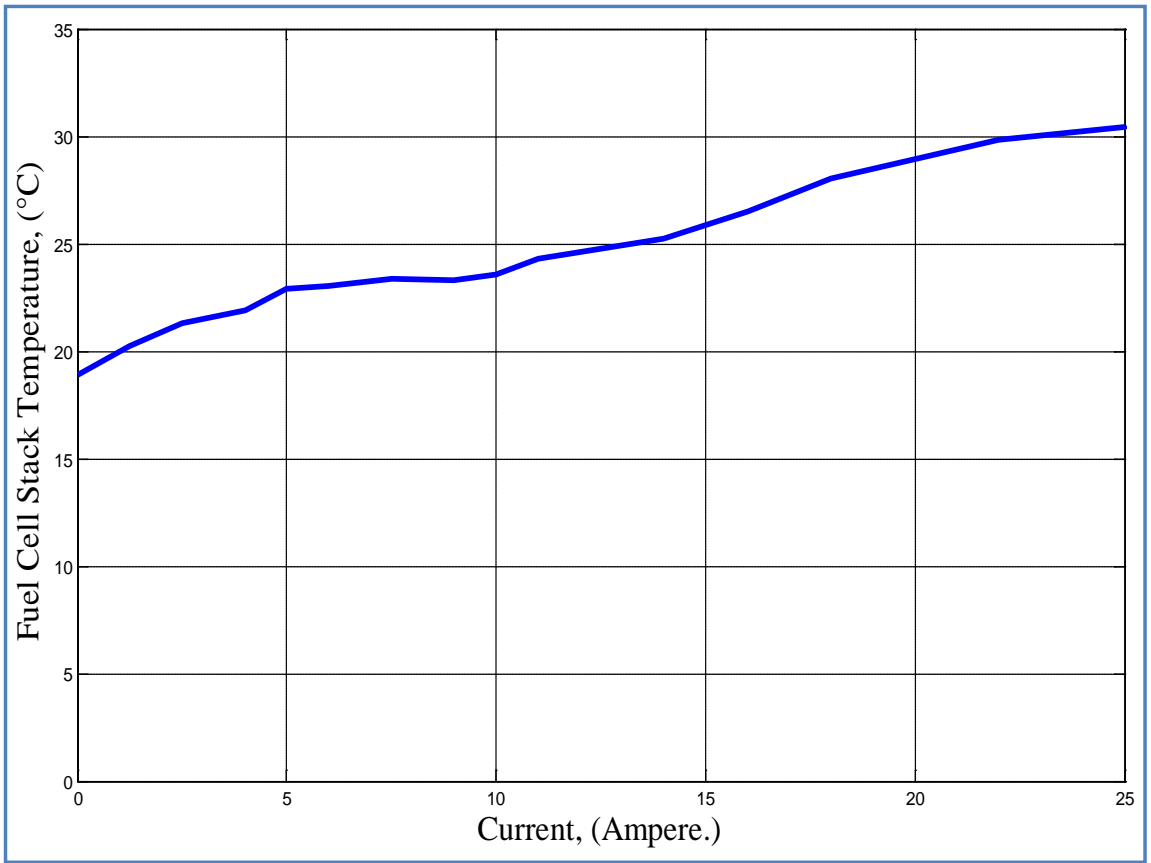

Figure 4. Impact of drawn current on the temperature of Horizon (H-1000) fuel cell stack. 


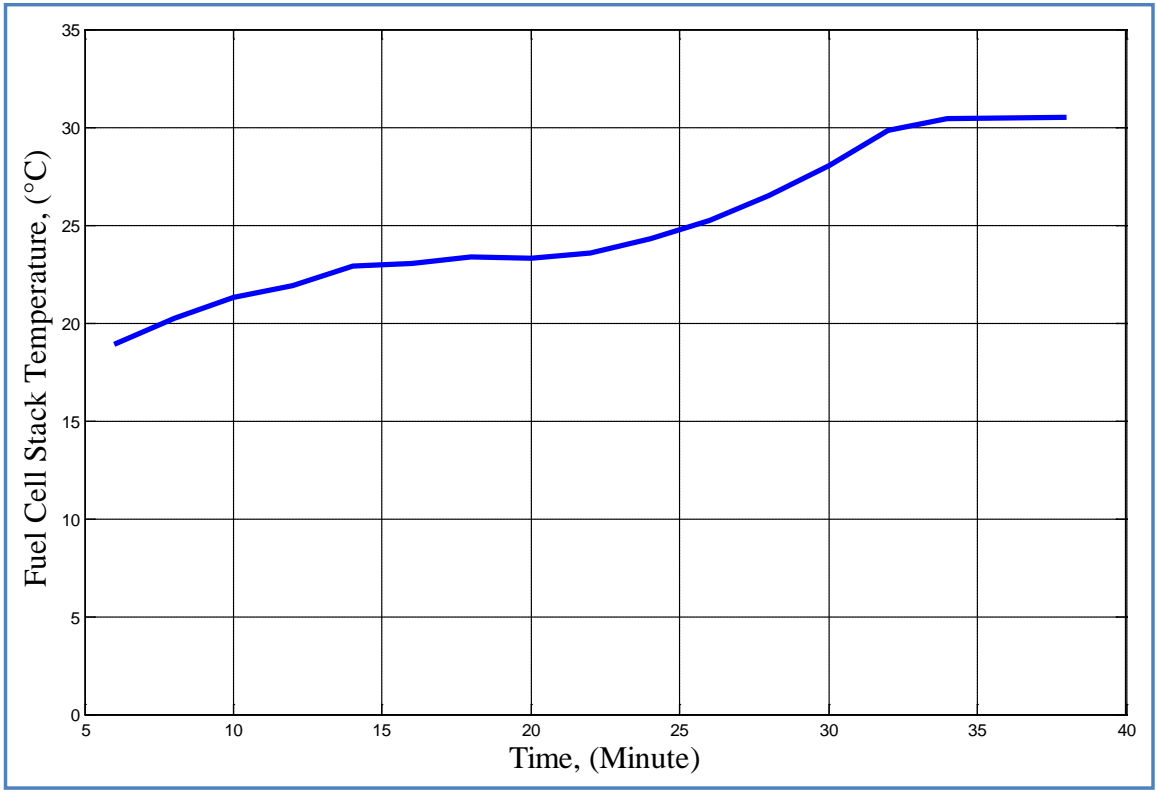

Figure 5. Impact time of operation at varied load current on the temperature of Horizon (H-1000) fuel cell stack.

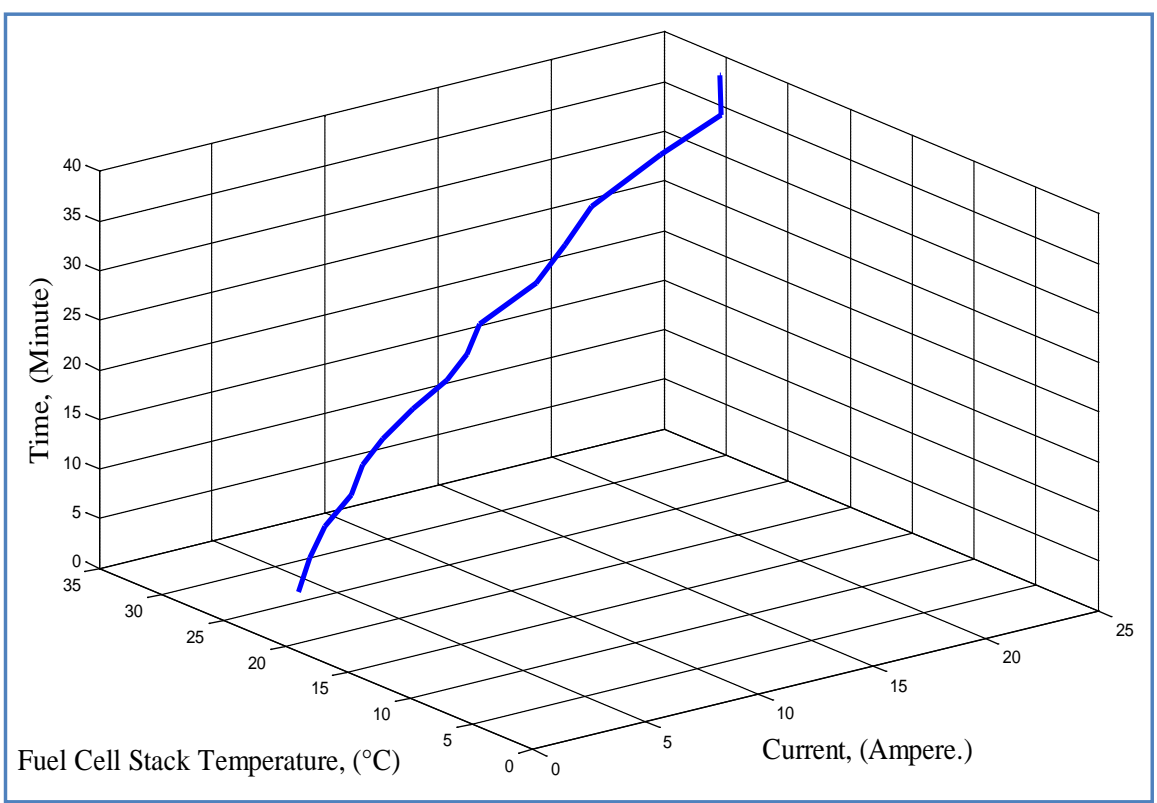

Figure 6. Impact of drawn current and time of operation on the temperature of Horizon (H-1000) fuel cell stack.

temperature measurements. Figure 7 shows the output voltages and drawn currents for the tested Horizon (H-1000) fuel cell stack, while Figure 8 shows the average of voltages for each level of current.

Different values of efficiency (83\%, 84\%, 85\%, and $86 \%$ ) for developed PEM fuel cell are adopted in order to find the best tuning value between the tested fuel cell stack and the developed model. It is noticed that the best value of efficiency for the developed model that enables the model to perform and produce output 


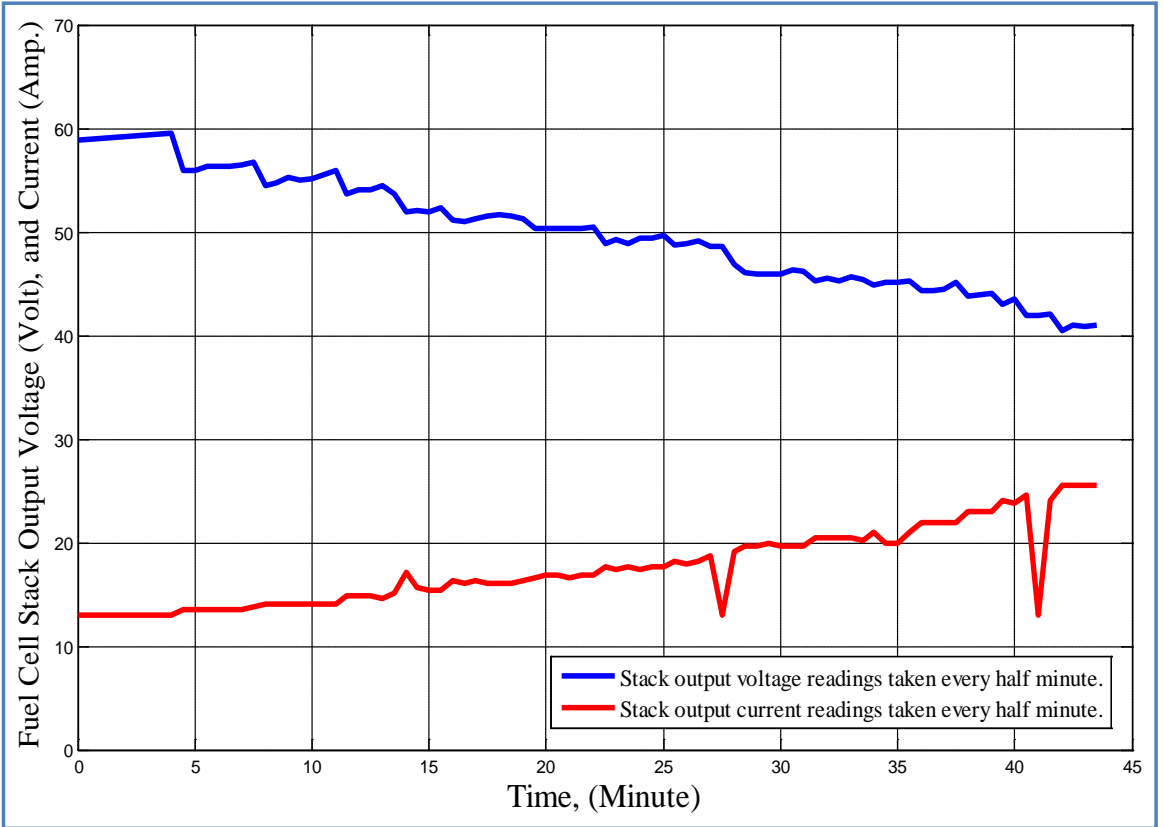

Figure 7. Output voltages and drawn currents for Horizon (H-1000) fuel cell stack.

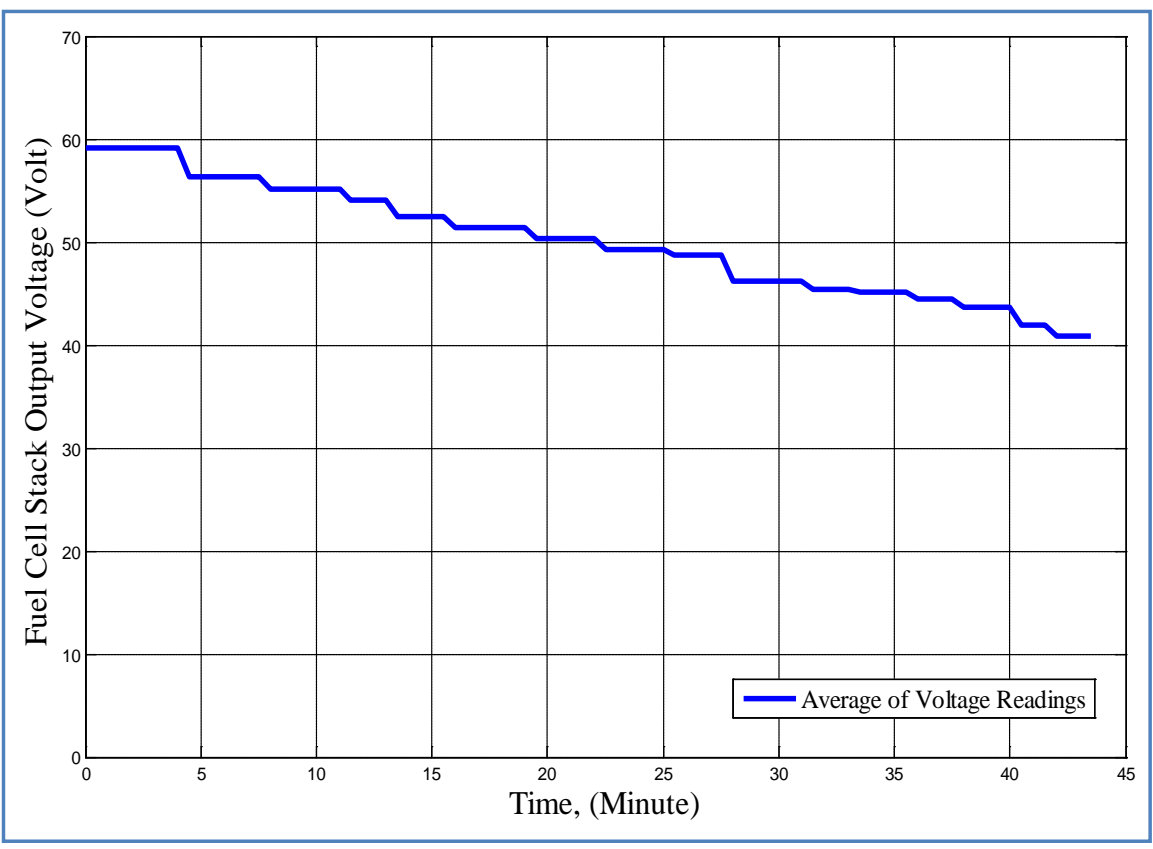

Figure 8. Average of output voltages for each level of drawn current for Horizon (H-1000) fuel cell stack.

voltages close to the real outputs of tested stack was at $85 \%$ with $1.44 \mathrm{~V}$ average of deviation between the stack test output voltages and output voltages of the developed model. Output voltages for the tested Horizon stack and for the developed model under varied stack temperatures and load currents, and the output voltages of the developed model at particularly $85 \%$ tuning efficiency and constant average stack Temperature $\left(27.73^{\circ} \mathrm{C}\right)$ are presented in Figure 9. The 
impact of drawn currents and time of operation upon the temperature of Horizon fuel cell stack are shown in Figures 10-12, respectively.

It can be noticed from Figure 9, that for the developed PEM fuel cell model at $85 \%$ tuning efficiency, there is very small variations between the output voltages of the model at varied stack's temperature (represented by red line) and the output voltages of the model at constant average stack's temperature of $27.73^{\circ} \mathrm{C}$ (represented by green line). Thus, $85 \%$ tuning efficiency and $27.73^{\circ} \mathrm{C}$ average

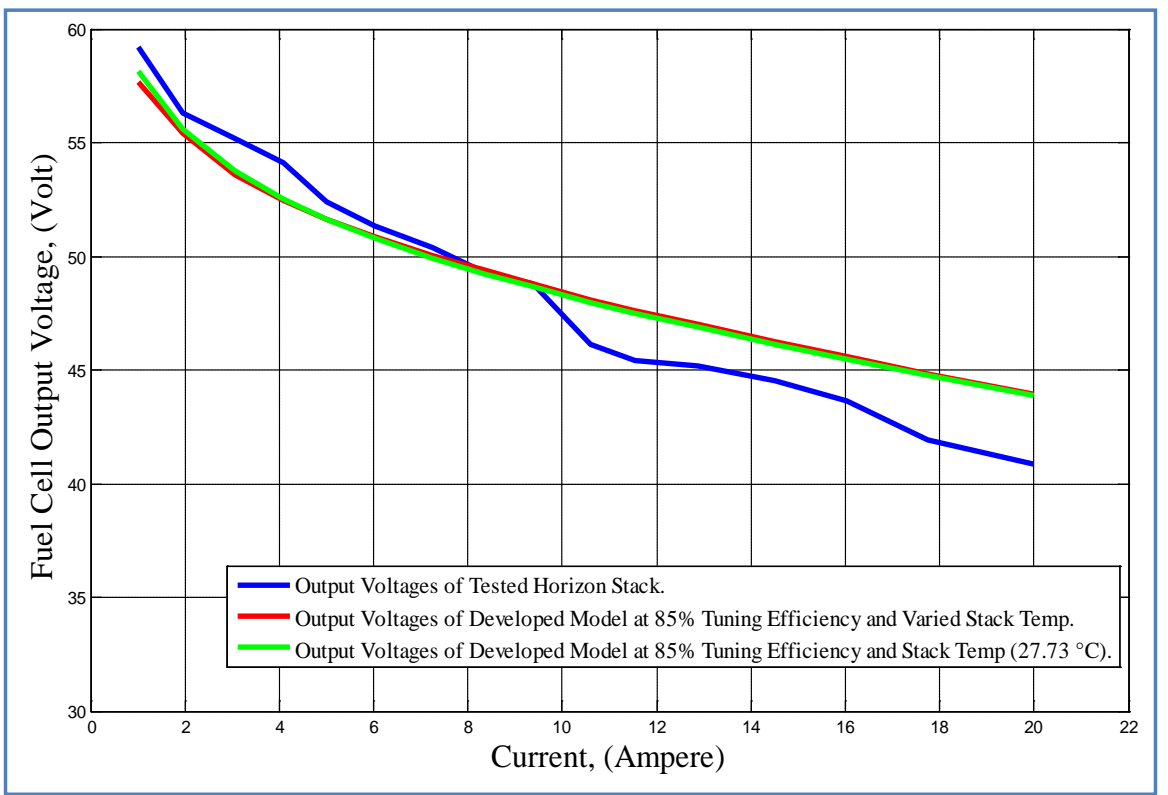

Figure 9. Output voltages of Horizon fuel cell stack test, and developed model of PEM fuel cell at varied stack temperature and load currents, and $85 \%$ tuning efficiency.

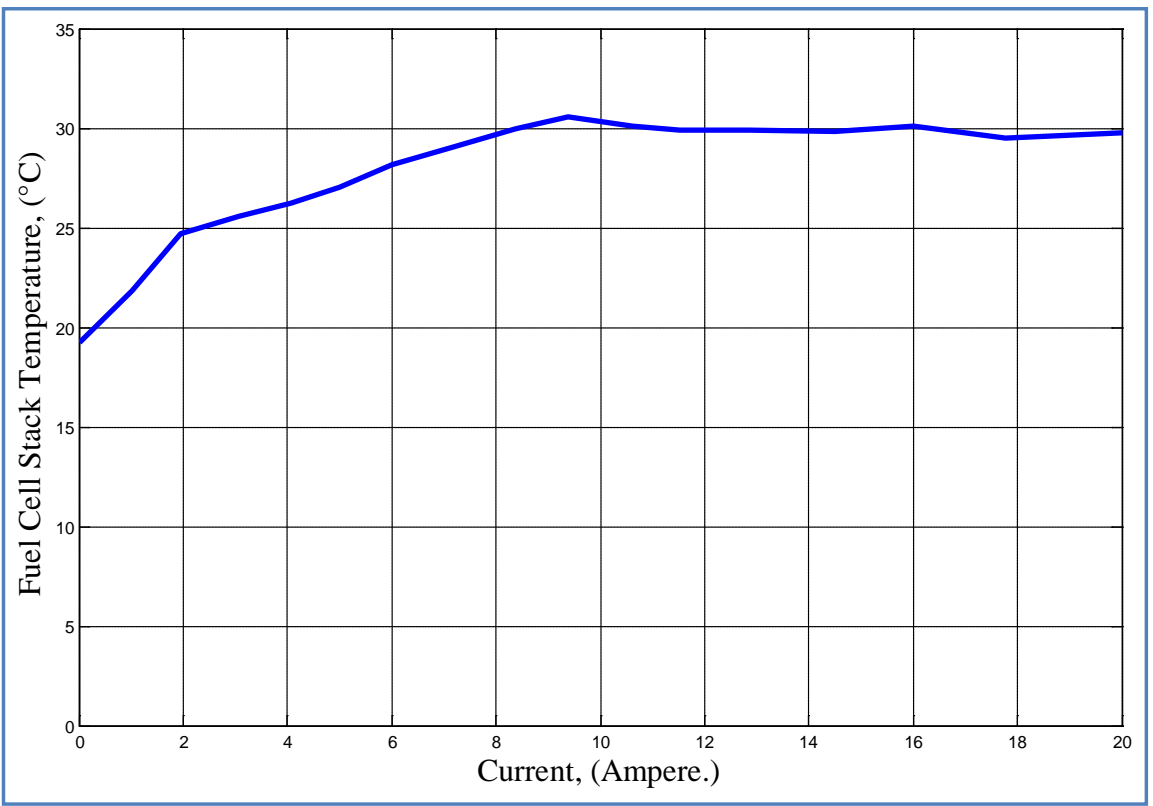

Figure 10. Impact of drawn current on the temperature of Horizon $(\mathrm{H}-1000)$ fuel cell stack. 


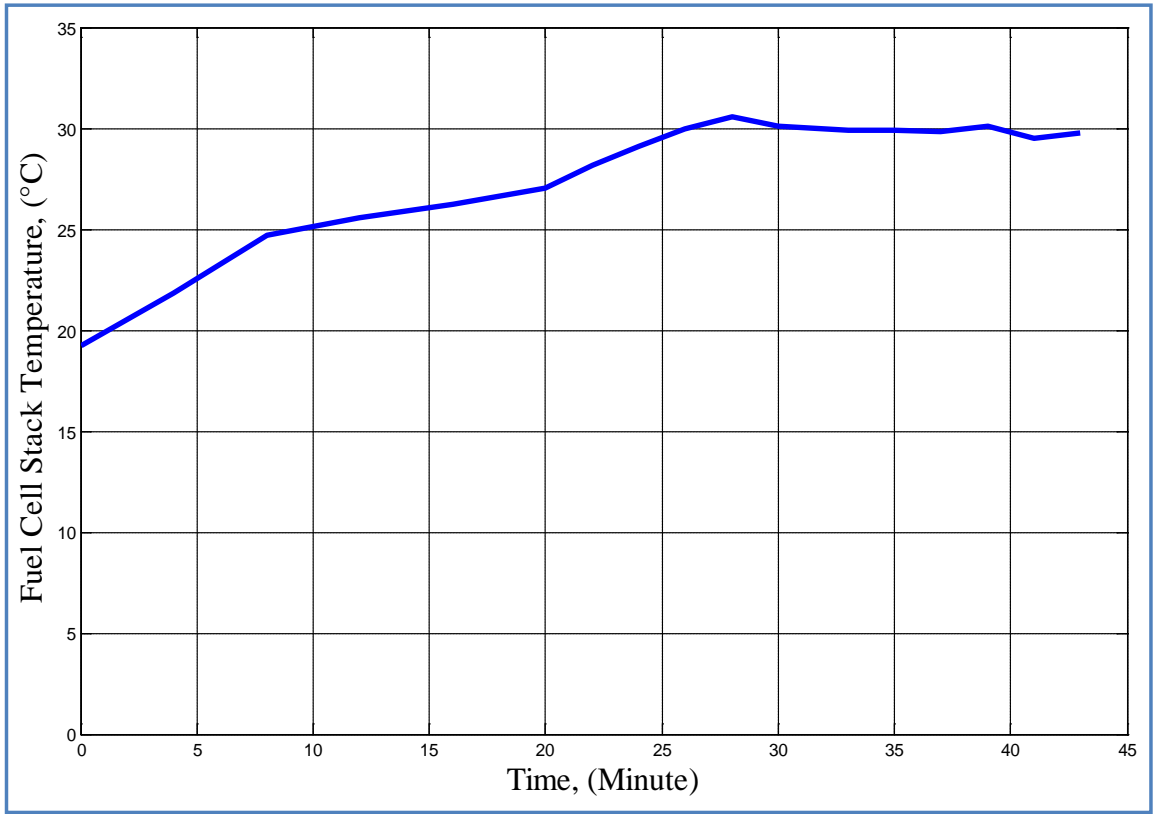

Figure 11. Impact of time of operation at varied current on the temperature of Horizon (H-1000) fuel cell stack.

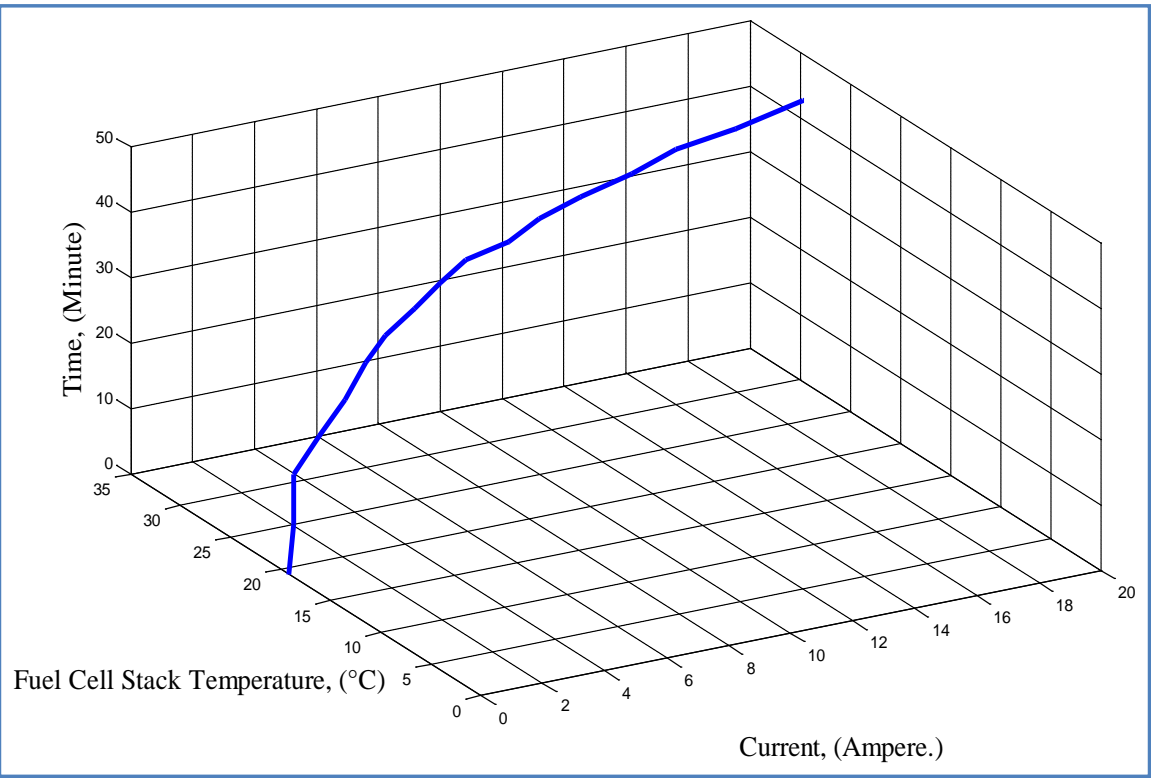

Figure 12. Impact of drawn current and time of operation on the temperature of Horizon (H-1000) fuel cell stack.

stack's temperature will be adopted for any further simulations for the developed mathematical model of PEM fuel cell in this research.

\subsection{Fourth Test}

Horizon (H-1000) PEM fuel cell stack is tested under atmospheric pressure and $21.5^{\circ} \mathrm{C}$ room temperature. Test is started after leaving the fuel cell stack for about one hour from the last running test in order to refresh and rest the stack. 
The stack is operated for about 32 minutes under constant load current (9.08 A). Four TH sensors are installed at the exit outlets of the four fans in order to have more accurate temperature measurements, and $\mathrm{TH}$ sensors readings are captured every two minutes. The impact of constant drawn load current and time of operation upon the temperature of Horizon fuel cell stack are measured and drawn in Figure 13. Output voltage of Horizon fuel cell stack under the impact of constant drawn current is almost stable around $51.6 \mathrm{~V}$ as shown in Figure 14. Where, the fluctuations in the output voltages as a result of the drop in the pressure of hydrogen in the anode chambers of Horizon PEM fuel cell stack due to frequent breathing process triggered by hydrogen purging valve are eliminated from the captured results.

It is clear from the results presented for the tested Horizon (H-1000) fuel cell stack that the stack's temperature has intendancy to increase with operating time and drawn current. The temperature of the stack is maintained around the level of $\left(30^{\circ} \mathrm{C}\right)$ even under further extend in operating time or further increase in the drawn current. This is returned to the potential role of stack's controller which works to suppress any further increase in the stack's temperature above $\left(30^{\circ} \mathrm{C}\right)$ by pumping more air to the cathode in order to maintain the operating temperature of the stack around certain level of operating temperature.

[21] Adopted a $100 \mathrm{~W}$ Horizon PEM fuel cell stack as prime source of power for small unmanned aircraft. The test results and the performance evaluation obtained from continuously operating the stack for about 5 hours under $50 \mathrm{~W}$ of constant load have shown that the temperature of the stack is increased from $22^{\circ} \mathrm{C}$ to $35^{\circ} \mathrm{C}$ for the first 30 minutes of stack's operation, while the stack's temperature is maintained below $35^{\circ} \mathrm{C}$ for the rest hours of the test.

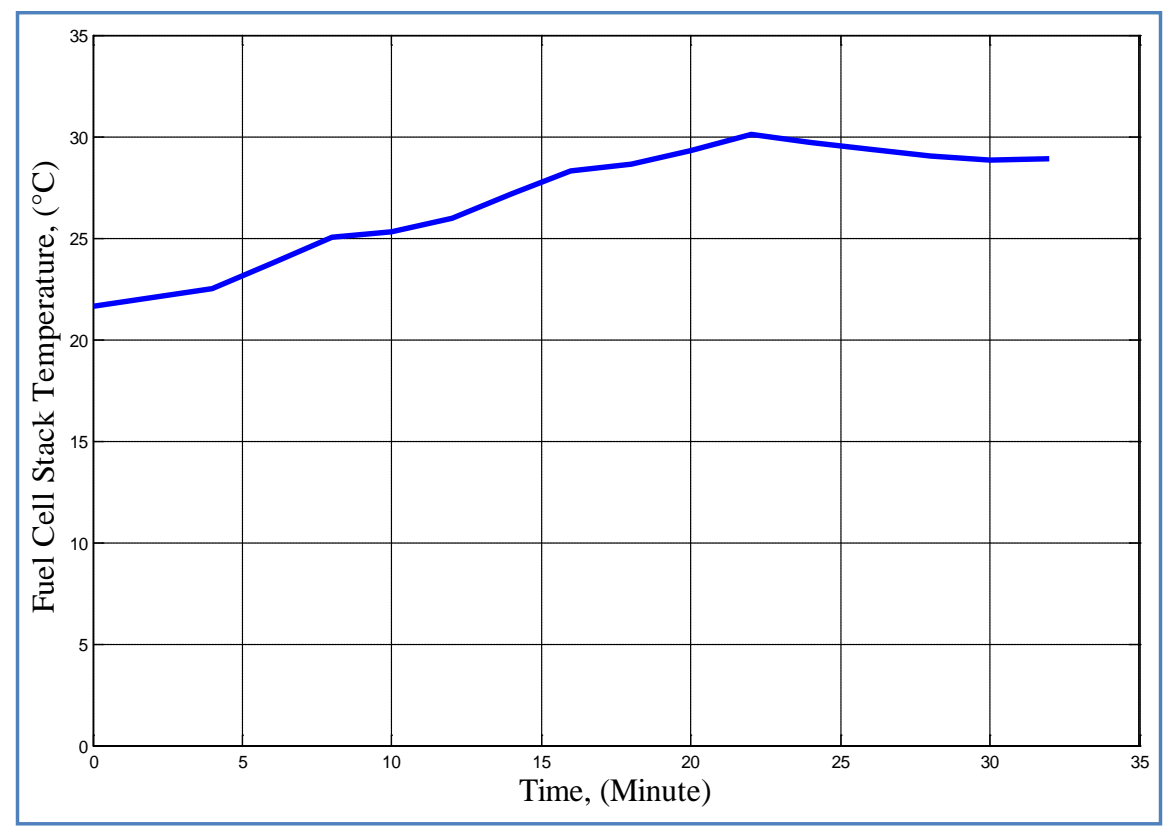

Figure 13. Impact of constant drawn current and time on the temperature of Horizon (H-1000) fuel cell stack. 


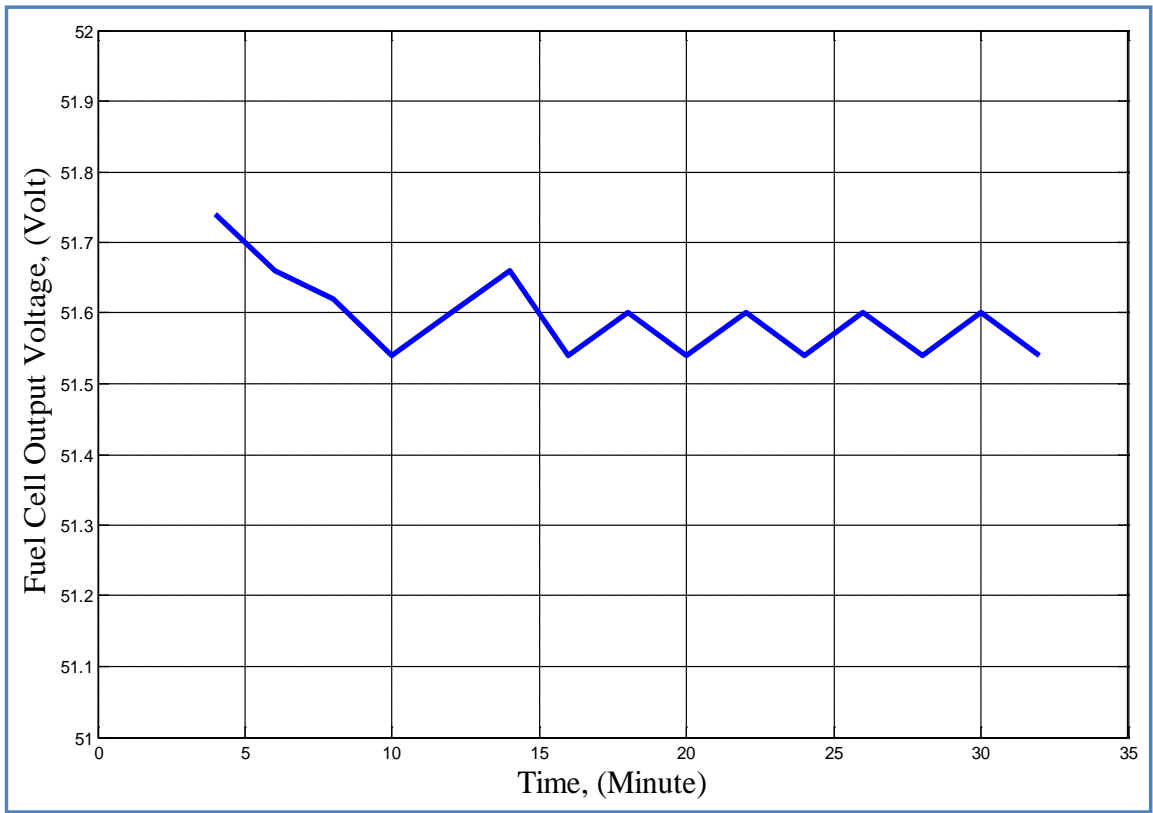

Figure 14. Output voltages of Horizon (H-1000) fuel cell stack under the impact of constant drawn current.

Furthermore, the observations from model simulations provide sufficient evidence and support to the results and observations obtained from testing $1 \mathrm{~kW}$ Horizon (H-1000) PEM fuel cell stack used in this research. The developed model can be used as a generic model and simulation platform for a self-humidifying PEM fuel cell with an output power varying from $50 \mathrm{~W}$ to 1 $\mathrm{kW}$, with extrapolation to higher powers is also possible.

\section{Conclusions}

This paper presents a validation of the zero dimensional mathematical model for a self-humidifying PEM fuel cell stack. The major electric and thermodynamic variables and parameters involved in the operation of the PEM fuel cell with the association of the influence of the environment and conditions of fuel cell operation are considered. A $1 \mathrm{~kW}$ Horizon (H-1000) PEM fuel cell stack is used as a prototype device in order to validate and tune the developed mathematical model with the output results of the test.

The results of testing $1 \mathrm{~kW}$ Horizon stack and the simulations of the developed mathematical model are presented for different changes in the operational variables in order to improve the accuracy of the model. The observations from model simulations provide sufficient evidence and support to the results and observations obtained from testing $1 \mathrm{~kW}$ Horizon PEM fuel cell stack used in this research. Moreover, the developed model can be used as a generic model and simulation platform for a self-humidifying PEM fuel cell with an output power varying from $50 \mathrm{~W}$ to $1 \mathrm{~kW}$, with extrapolation to higher powers is also possible.

Further works need to be carried out in the future to extend the developed 
model to implicit the impact of produced heat as a result of electrochemical reaction and the impact of the friction of the flowing reactants inside the fuel cell on the performance and power output of PEM fuel cell stack.

\section{Acknowledgements}

The authors would like to thank Dr. George Pissanidis and Leonine Kunzwa from School of Engineering \& Technology at the University of Hertfordshire for their assistance and technical support during the field of experiments.

\section{References}

[1] Golbert, J. and Lewin, D.R. (2004) Model-Based Control of Fuel Cells: (1) Regulatory Control. Journal of Power Sources, 135, 135-151. https://doi.org/10.1016/j.jpowsour.2004.04.008

[2] Jing, Q.I.U., Dong, Z.Y., Zhao, J.H., Meng, K., Luo, F.J., Wong, K.P. and Lu, C. (2015) A Low-Carbon Oriented Probabilistic Approach for Transmission Expansion Planning. Journal of Modern Power Systems and Clean Energy, 3, 14-23. https://doi.org/10.1007/s40565-015-0105-3

[3] El-Sharkh, M.Y., Rahman, A., Alam, M.S., Byrne, P.C., Sakla, A.A. and Thomas, T. (2004) A Dynamic Model for a Stand-Alone PEM Fuel Cell Power Plant for Residential Applications. Journal of Power Sources, 138, 199-204. https://doi.org/10.1016/j.jpowsour.2004.06.037

[4] Rodatz, P., Paganelli, G., Sciarretta, A. and Guzzella, L. (2005) Optimal Power Management of an Experimental Fuel Cell/Supercapacitor-Powered Hybrid Vehicle. Journal of Control Engineering Practice, 13, 41-53. https://doi.org/10.1016/j.conengprac.2003.12.016

[5] Bordons, C., Arce, A. and Real, A.J.D. (2006) Constrained Predictive Control Strategies for PEM Fuel Cells. American Control Conference, Minneapolis, 14-16 June 2006, 2486-2491.

[6] Chen, S.-L., Bocarsly. A.B. and Benziger, J. (2005) Nafion-Layered Sulfonated Polysulfone Fuel Cell Membranes. Journal of Power Sources, 152, 27-33. https://doi.org/10.1016/j.jpowsour.2005.03.214

[7] Springer, T.E., Zawodzinski, T.A. and Gottesfeld, S. (1991) Polymer Electrolyte Fuel Cell Model. Journal of the Electrochemical Society, 138, 2334-2342. https://doi.org/10.1149/1.2085971

[8] Büchi, F.N. and Scherer, G.G., (1996) In-Situ Resistance Measurements of Nafion ${ }^{\circledR}$ 117 Membranes in Polymer Electrolyte Fuel Cells. Journal of Electroanalytical Chemistry, 404, 37-43. https://doi.org/10.1016/0022-0728(95)04321-7

[9] Yi, J.S. and Nguyen, T.V. (1998) An Along-the-Channel Model for Proton Exchange Membrane Fuel Cells. Journal of the Electrochemical Society, 145, 1149-1159. https://doi.org/10.1149/1.1838431

[10] Pukrushpan, J.T., Stefanopoulou, A.G. and Peng, H. (2002) Modeling and Control for PEM Fuel Cell Stack System. Proceedings of American Control Conference, Anchorage, 8-10 May 2002, 3117-3122.

[11] Rowe, A. and Li, X. (2001) Mathematical Modeling of Proton Exchange Membrane Fuel Cells. Journal of Power Sources, 102, 82-96. https://doi.org/10.1016/S0378-7753(01)00798-4

[12] Pasricha, S. and Shaw, S.R. (2006) A Dynamic PEM Fuel Cell Model. IEEE Transac- 
tions on Energy Conversion, 21, 484-490. https://doi.org/10.1109/TEC.2005.860402

[13] del Real, A.J., Arce, A. and Bordons, C. (2007) Development and Experimental Validation of a PEM Fuel Cell Dynamic Model. Journal of Power Sources, 173, 310-324. https://doi.org/10.1016/j.jpowsour.2007.04.066

[14] Park, S.-K. and Choe, S.-Y. (2008) Dynamic Modeling and Analysis of a 20-Cell PEM Fuel Cell Stack Considering Temperature and Two-Phase Effects. Journal of Power Sources, 179, 660-672. https://doi.org/10.1016/j.jpowsour.2008.01.029

[15] Youssef, M.E., AL-Nadi, K.E. and Khalil, M.H. (2010) Lumped Model for Proton Exchange Membrane Fuel Cell (PEMFC). International Journal of Electrochemical Science, 5, 267-277.

[16] Yuan, W., Tang, Y., Pan, M., Li, Z. and Tang, B. (2010) Model Prediction of Effects of Operating Parameters on Proton Exchange Membrane Fuel Cell Performance. Renewable Energy, 35, 656-666. https://doi.org/10.1016/j.renene.2009.08.017

[17] Seyezhai, R. and Mathur, B.L. (2011) Mathematical Modeling of Proton Exchange Membrane Fuel Cell. International Journal of Computer Applications, 20, 1-6. https://doi.org/10.5120/2433-3272

[18] Saleh, I.M.M., Ali, R. and Zhang, H. (2016) Simplified Mathematical Model of Proton Exchange Membrane Fuel Cell Based on Horizon Fuel Cell Stack. Journal of Modern Power Systems and Clean Energy, 4, 668-679. https://doi.org/10.1007/s40565-016-0196-5

[19] Saleh, I.M.M., Calay, R.K. and Rashid, A. (2013) Modelling and Examining Open Circuit Voltage for PEM Fuel Cell. Journal of Electrical Engineering, 13, 140-146.

[20] Horizon Fuel Cell Technology (2011) H-1000 Fuel Cell Stack-User Manual.

[21] Kim, T. and Kwon, S. (2012) Design and Development of a Fuel Cell-Powered Small Unmanned Aircraft. International Journal of Hydrogen Energy, 37, 615-622. https://doi.org/10.1016/j.ijhydene.2011.09.051

\section{Appendix A}

Table A1. Variables and constants of the operational parameters involved in the developed model of PEM fuel cell stack.

\begin{tabular}{cc}
\hline Variables and Constants & Defined Values \\
\hline Number of cells in the stack & 72 \\
Active area of electrolyte membrane & $80 \mathrm{~cm}^{2}$ \\
Water content in electrolyte membrane $(\lambda)$ & 7 \\
Membrane thickness $(L)$ & $25 \times 10^{-4} \mathrm{~cm}$ \\
Maximum current density $\left(i_{m}\right)$ & $500 \mathrm{~mA} / \mathrm{cm}^{2}$ \\
Maximum output voltage & $43.2 \mathrm{~V}$ at $24 \mathrm{~A}$ \\
Maximum stack operating temperature & $65^{\circ} \mathrm{C}$ \\
Temperature of supply air and hydrogen & Room temperature \\
Ambient pressure & $101.325 \mathrm{kPa}$ \\
Ambient air density & $1.225 \mathrm{~kg} / \mathrm{m}^{3}$ \\
Pressure of supply Hydrogen & $55 \mathrm{kPa}$ \\
Density of supply Hydrogen & $0.899 \mathrm{~m}^{3}$ \\
\hline
\end{tabular}

